\title{
Rodolfo Usigli Centennial: An Interdisciplinary Commemoration
}

\section{Ramón Layera}

Miami University in Oxford, Ohio held a series of interdisciplinary activities as part of the Rodolfo Usigli centennial celebration in the fall of 2005. The events included a semester-long library exhibit, a staged reading of Usigli's signature play El gesticulador and an international symposium on contemporary Mexican theatre. Miami University was the logical site for this commemoration as it is the privileged home of the Rodolfo Usigli Archive in the Walter Havighurst Special Collections Library; furthermore, Miami's centennial celebration was developed in concert with the Centro Nacional de Investigación Teatral Rodolfo Usigli (CITRU), the Universidad Nacional Autónoma de México (UNAM), the Instituto Nacional de Bellas Artes (INBA) and Universidad Iberoamericana, which also sponsored separate events and exhibits in Mexico. The activities held on the Miami campus were the following:

\section{Library exhibit}

Starting in September the Walter Havighurst Special Collections Library held "Rodolfo Usigli in Mexican Literature and the Arts," a semesterlong exhibit of materials from the Usigli Archive, the definitive research collection relating to Usigli's life and career. Accompanying the exhibit a website provided details about the archive and the materials that were on display. The exhibit included biographical information and details about Usigli's life and career as playwright, theatre historian and educator and diplomat. It also provided links to visual and documentary materials from the Archive, including manuscripts, photographs, correspondence, posters and stage designs of productions of his plays. Special Collections also prepared a descriptive catalog with information about and images of the library exhibit. The catalog was made available to the public throughout the fall semester. Copies of the 


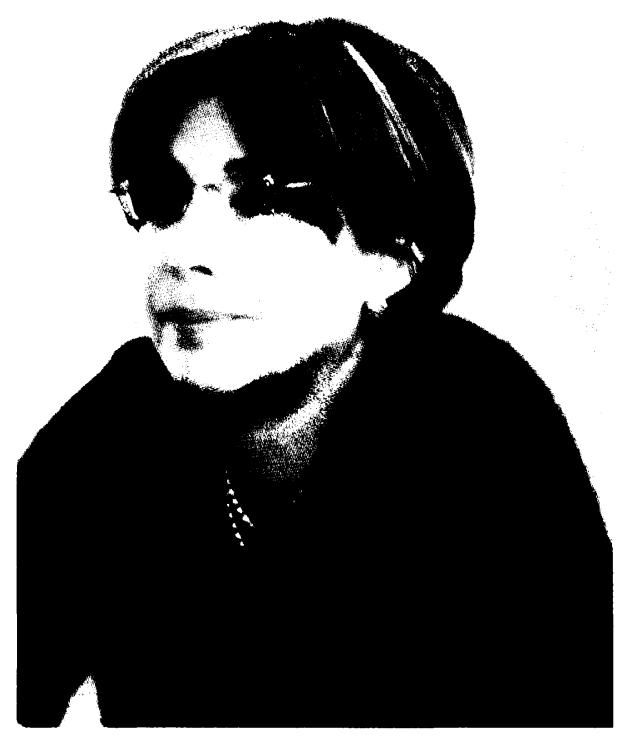

Sabina Berman

catalog of the exhibit can be obtained by writing to Janet Stuckey at: stuckejh@muohio.edu. An online version of the catalog is available from the library website: http:// usigli.lib. muohio.edu/archive.php.

Upon the request of the CITRU, Special Collections agreed to prepare facsimile copies of the materials that were displayed at Miami University in Ohio. The materials were shipped to Mexico for display at the Instituto Nacional de Bellas Artes (INBA) and at the CITRU in the Centro Nacional de las Artes (CENART) complex. Professor Octavio Rivera of the Universidad de las AméricasPuebla (UDLA) served as curator

for the exhibit that was held at the INBA. He spent a week in Oxford working with the staff at Special Collections and he helped identify and prepare the materials that were sent to Mexico. Judith Sessions, Dean of University Libraries and Janet Stuckey, Head of Special Collections, both of Miami University, traveled to Mexico City and participated as invited guests in the inauguration of the Usigli commemorative exhibit that was organized at the INBA. The exhibit was also displayed at the campus of the Universidad Autónoma de México (UNAM) and at the Universidad Iberoamericana in Mexico City. Professor José Luis Ibáñez, visiting resident director was the Featured Speaker at the general meeting of the Friends of the Miami University Libraries in November, 2005. The title of his lecture was: "Rodolfo Usigli: Playwright, Translator, Social Critic."

\section{Staged reading of an Usigli play and guest director residency.}

The Department of Theatre and the Department of Spanish and Portuguese at Miami University hosted distinguished Mexican theatre director José Luis Ibáñez during a three-week residency. Prior to his arrival the Department of Theatre selected a cast, conducted preliminary rehearsals and made the necessary preparations for a public staged reading of Usigli's 
play The Impostor (English translation of El gesticulador) in Studio 88 at the Center for Performing Arts. Upon his arrival Señor Ibáñez assumed his role as director and he worked with the cast in preparation for the staged reading. Professor José Luis Ibáñez teaches acting, dramatic theory and composition at the School of Letters of the Universidad Nacional Autónoma de México (UNAM). With a distinguished career in professional and university theatre Ibáñez is recognized as one of Mexico's most successful and accomplished contemporary directors. He is well-known for his work in musical comedies, but especially as director of classical and contemporary drama from Europe, Latin America and the United States. In 1999 and 2004 he directed Golden Age plays at the annual International Siglo de Oro Festival at the Chamizal Theatre in El Paso, Texas. In 2000 he was a visiting Professor of Theatre at Hebrew University in Israel. Ibánez received the prestigious National University Prize for his creative endeavors in 2001. The public reading of Usigli's The Impostor coincided with the international symposium and it allowed both symposium participants and the public to attend the production.

\section{International Symposium on modern Mexican drama.}

The Department of Spanish and Portuguese at Miami University held "Into the Mainstream: Women in Modern Mexican Drama," a public two-day symposium (November 11-12) on the occasion of Usigli's centennial, with a focus on the importance of women in recent drama. The main focus of the symposium underscored the fact that Usigli not only designed strong

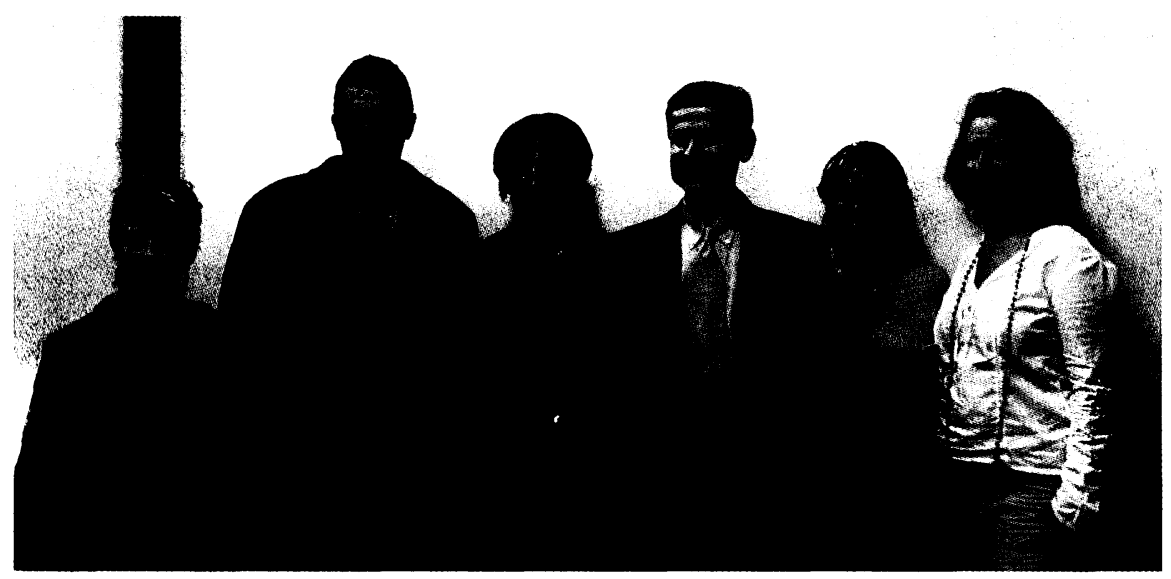

Kirsten Nigro, Stuart Day, Sabina Berman, Ramón Layera, Jacqueline Bixler, Francine A’Ness 
and assertive female characters in several of his plays but also two of Usigli's protégées, Rosario Castellanos and Luisa Josefina Hernández, became important female voices on the Mexican stage. The symposium included the participation of internationally-known playwright Sabina Berman and Mexican drama specialists Francine A'Ness (Dartmouth College), Jacqueline Bixler (Virginia Tech), Stuart Day (University of Kansas), and Kirsten Nigro (University of Texas-El Paso). Professor José Luis Ibáñez also participated in the symposium. As part of the symposium there was a public viewing of the film that is based on Sabina Berman's play Entre Villa y una mujer desnuda (Between Pancho Villa and a Naked Woman). During the first day of the symposium Kirsten Nigro spoke about "Generations of Mexican dramaturgas: Berta Hiriart, Estela Leñero, and Ximena Escalante," and Francine A'Ness spoke about "Making a Difference: Six Spectacular Women of the Mexican Stage." That afternoon Sabina Berman gave the first of two major addresses at the symposium. The next day Jacqueline Bixler focused on "The Politics of Transculturation and Tr/adaptation in the Recent Theatre of Sabina Berman" while Stuart Day concentrated on "Other Weapons: Politics and Parody in Backyard by Sabina Berman." The distinguished guest speaker, Sabina Berman, closed the symposium with a profound meditation on the nature of her art. On both days the guest speakers participated in an open discussion of recent theatrical trends in Mexico as well as a debate on the role of women as both creators and performers on the contemporary Mexican stage.

The interdisciplinary commemoration was supported by a generous grant from the John W. Altman Humanities Scholar-in-Residence Program, the Center for American and World Cultures, the College of Arts and Sciences and several other departments and programs at Miami University.

Miami University (Oxford,Ohio) 